\title{
The role of cognitive fusion, distress tolerance and self-compassion in post traumatic growth of abused individuals in their childhood
}

\author{
Sajjad Basharpoor $^{1}$, Mehri Mowlaie ${ }^{2}$, Leila Sarafrazi ${ }^{3}$ \\ 1-Professor, Department of Psychology and Educational Sciences, University of Mohaghegh Ardabili, Ardabil, Iran \\ (Corresponding Author). $\quad$ E-mail: Basharpoor_sajjad@yahoo.com \\ 2- Ph.D of Psychology, Department of Psychology and Educational Sciences, University of Mohaghegh Ardabili, \\ Ardabil, Iran. \\ 3- MA of Psychology, Department of Psychology and Educational Sciences, University of Mohaghegh Ardabili, \\ Ardabil, Iran.
}

Received: $15 / 03 / 2020$

Accepted: $23 / 04 / 2020$

\begin{abstract}
Introduction: Child abuse and harsh childhood experiences have long-lasting and unpleasant consequences on personality development and adaptation in adulthood.

Aim: The aim of the present research was to determine the role of cognitive fusion, distress tolerance and self-compassion on predicting post traumatic growth of abused indvduals in their childhood.

Method: The method of the present research was descripptive correlation study. The population included whole abused subjects over 15 years old who referred to psychiatric and counseling centers of Shiraz in the first half of the 2017. One hundred and ninety subjects were selected by available sampling method. In order to gather the data, Child trauma questionnaire (1998), cognitive fusion scale (2014), distress tolerance questionnaire (2005), self-compassion questionnaire (2003) and post-traumatic growth scale (1996) were used. The data were analyzed using Pearson correlation coefficient and multiple regression analysis via SPSS-22 software.

Results: The results showed that there was significantly negative relationship between cognitve fusion and post traumatic growht $(\mathrm{P}<0.01)$, and positive relationship between distress tolerance and self-compassion with post traumatic growht $(\mathrm{P}<0.01)$. Although, the results indicated that cognitive fusion could not predict post traumatic growht but another two variables could explain $41 \%$ variance of post traumatic growht.

Conclusion: According to the findings of this study, it can be concluded that psychological factors play significant roles in post traumatic growth . In treatment interventions, attention to these factors can be helpful in adapting to child abuse individuals.
\end{abstract}

Keywords: Cognitive fusion, Distress tolerance, Self-compassion, Post traumatic growth, Child abuse

How to cite this article : Basharpoor S, Mowlaie M, Sarafrazi L. The role of cognitive fusion, distress tolerance and self-compassion in post traumatic growth of abused individuals in their childhood. Shenakht Journal of Psychology and Psychiatry. 2020; 7 (3): 87-100 .URL: http://shenakht.muk.ac.ir/article-1-700-en.pdf

Copyright ( 2018 the Author (s). Published by Kurdistan University of Medical Sciences. This is an open access article distributed under the terms of the Creative Commons Attribution-Non Commercial License 4.0 (CCBY-NC), where it is permissible to download, share, remix, transform, and buildup the work provided it is properly cited. The work cannot be used commercially without permission from the journal. 


\title{
نقش آميختكى شناختى، تحمل آشفتكى و دلسوزى به خود

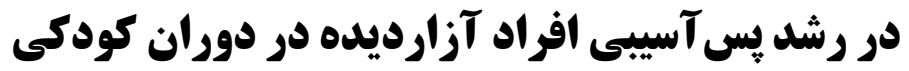

\begin{abstract}
سجاد بشريور'، مهرى مولايى '، ليلا سر افرازى"
ا.استاد، گروه روانشناسى و علوم تربيتى، دانشكاه محقق ارديبلى، اردبيل، ايران (مولف مسئول). ايميل: Basharpoor_sajjad @yahoo.com

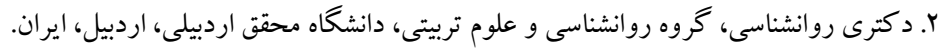
r. كارشناسى ارشد روانشناسى، گروه روانشناسى و علوم تربيتى، دانشخاه محقق اردبيلى، اردبيل، ايران.
\end{abstract}

مقدمه: كودككآزارى و تجربيات ناكوار دوران كودكى داراى آثار و ييامدهاى درازمدت و ناخوشايندى بر تحول و ساز كارى شخصيت در دوران بزر گسالى است.

هدف: هدف يُزوهش حاضر بررسى نقش آميختحى شناختى، تحمل آشفتكى و دلسوزى به خود در رشد بِ آسيبى افراد آزارديده در دوران كودكى بود.

روش: روش ئزوهش حاضر، توصيفى از نوع همبستخى بود. جامعه آمارى اين ئزهش را تمامى افراد آزارديده بالاتر از ها سال

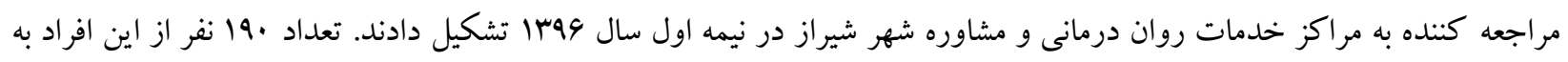

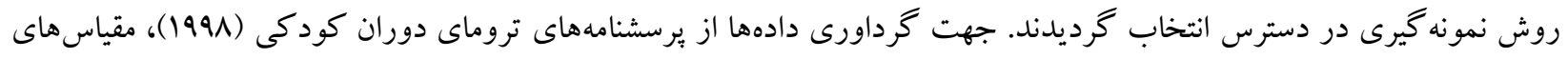

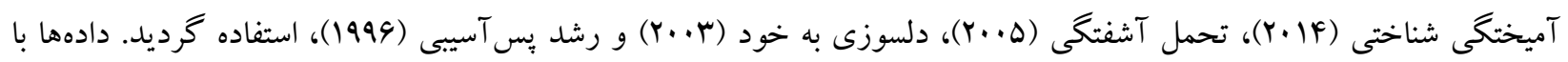

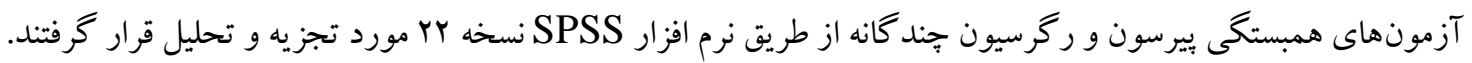

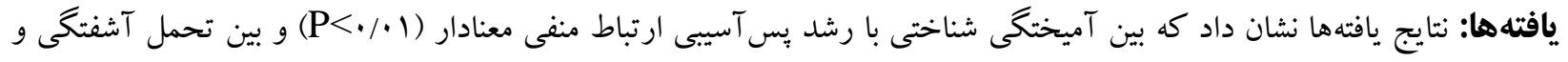

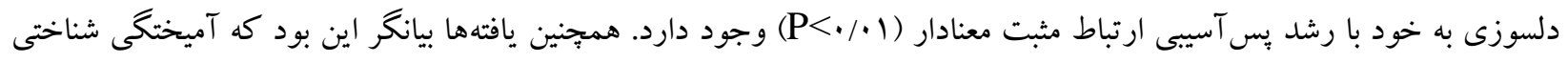

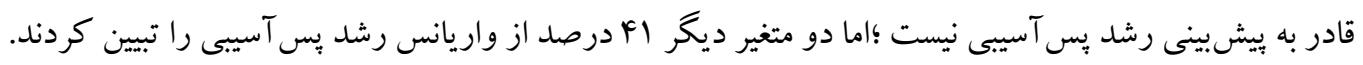
نتيجه كيرى: با توجه به يافته هاى يُزوهش حاضر، مىتوان نتيجه گرفت كه عوامل روانشناختى در رشد بِ آسيبى نقش بسز ايى دارند و در مداخلات درمانى توجه به اين عوامل مى تو اند در ساز كارى افراد آسيب ديده كمكك شايانى نمايد. كليدوازهها: آميختخى شناختى، تحمل آشفتكى، دلسوزى به خود، رشد بِ آسيبى، كودك آزارى 
اهميت انطباقى است (تدسجى و كالهون"' 1999).

تدسجى (1999) معتقد است اثرات انطباقى تروما به

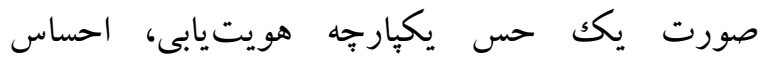

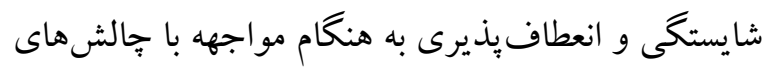

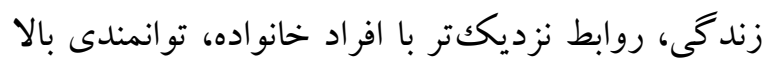
براى محافظت از خود و جلو گيرى از سوءاستفاده، نوع- رون دوستى بيشتر، گشود خى بالا براى رفتارهاى جديد، عقايد

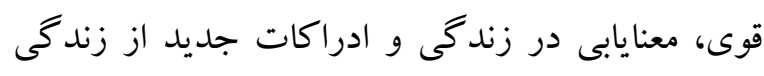
ظاهر مىشود؛بنابراين با مطرح شدن مفهوم رشد يس

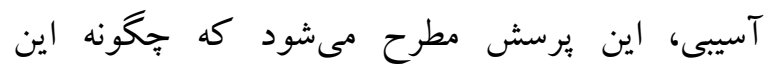

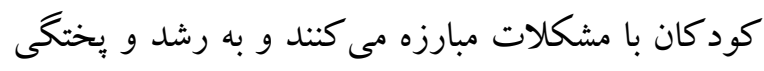
پِ از آسيب دست مىيابند؟ در بِاسخ به اين سؤال، بثزوهشكران بر نقش عوامل ميانجى رشد بِ بسآسيى و آسيب هاى روان شناختى متمركز شدهاند. يكى از اين عوامل ميانجى مهم، آميختكى شناختى است. آميختكى شناختى بازتاب يكك بديده روانشناختى است كه در آن

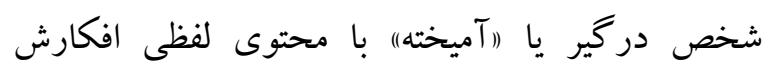
مىشود. در طى دو دهه اخير يُزوهشهاى زيادى در حمايت از نقش فرا تشخيصى و آسيبزا بودن آميختكى شناختى به عنوان يك فرايند بنيادين در سببشناسى اختلالهاى روانشناختى ازجمله اختلال افسردگى لئى (باردين و فركوس "'، 19.r)، اختلالهاى سايكو تيكك

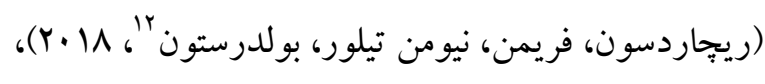

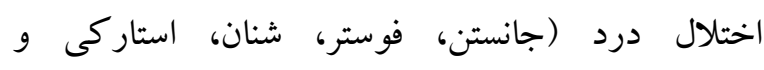

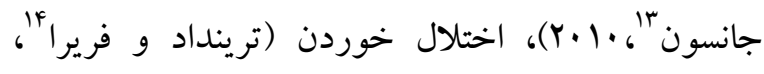

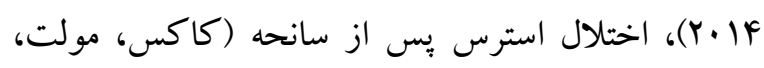

${ }^{10}$ - Tedeschi \& Calhoun

${ }^{11}$ - Bardeen \& Fergus

${ }^{12}$ - Richardson, Freeman, Newman-Taylor, Bolderston

${ }^{13}$ - Johnston, Foster, Shennan, Starkey \&Johnson

${ }^{14}$ - Trindade \& Ferreira
كودكآزارى در جهان شيوع بالايى دارد (ون دركويج

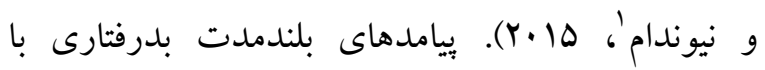
كودك اغلب شديد و كسترده بوده و بهويزه با اختلال

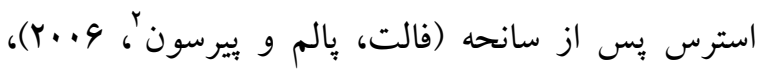

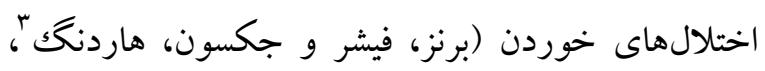

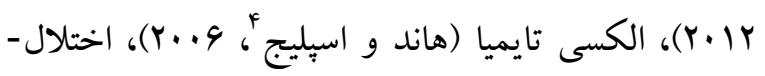
هاى روانيريشى (شيفر، هارفست، آدرهولد، بريكن،

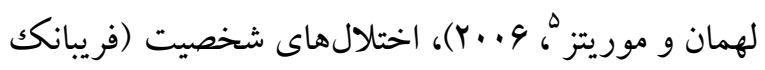

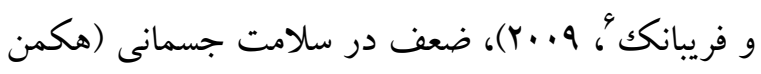

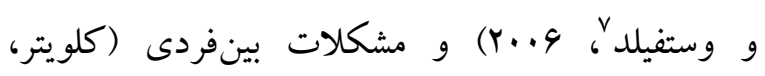

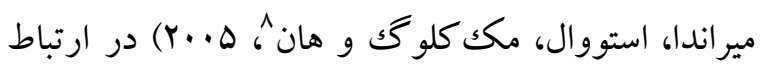
است. گر جه مطالعات بيانكر ارتباط بين كودك آزارى و اختلالهاى ذكر شده در بالا هست ؛اما همه افرادى كه آزارهاى كودكى را تجربه كردهاند دجار اختلالهاى روانى، رفتارى و مشكلات ذكر شده نمىشوند. سيجتى و كارمز" (1994) در بروسى دويست كودك ورك و خانوادههايشان دريافتند كه بعضى از كودكان با وجود شرايط نامساعد، كار آمد بودند و هيج مشكل رفتارى نداشتند و حتى رشد روانشناختى بس از آسيب را نيز از خود نشان مى دهند. رشد بس آسيب كه توسط تدسجى مطرح شده است به تغييرات شخصى و روانشناختى مثبى كفته مىشود كه بس از وقوع يكك حادثه سخت ايجاد مىشود و نتيجه مبارزه فرد عليه اين حادثهى استرسزا است كه داراى

\footnotetext{
1. Van der Kooij \& Nieuwendam

2. Follette, Palm \& Pearson

3 - Burns, Fischer, Jackson \& Harding

4. Hund \& Espelage

5 - Schäfer, Harfst, Aderhold, Briken, Lehmann \& Moritz

6. Fairbank \& Fairbank

7. Heckman \& Westefeld

8 - Cloitre, Miranda, Stovall-McClough \& Han

${ }^{9}$ - Cicchettti \& Garmezy
} 
فراهم كند، دلسوزى به خود است. افراد دلسوز به خود از سلامت روان بهترى برخوردارند (بشريور، عqسا). دلسوز بودن نسبت به خود با بهزيستى كلى و ديخر صفات

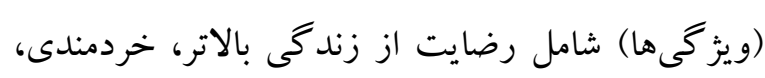

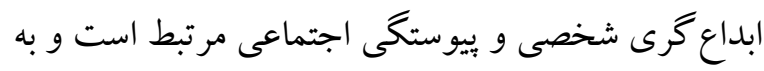

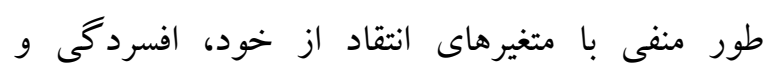

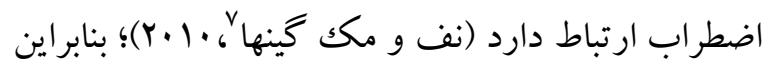
با توجه به اينكه كودكك آزارى مشكلى فراكير است و نيز

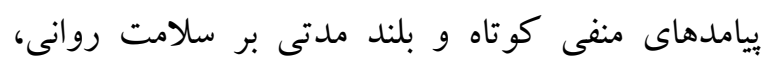
جسمانى، مهارتهاى شناختى و رشد اجتماعى و رفتارى

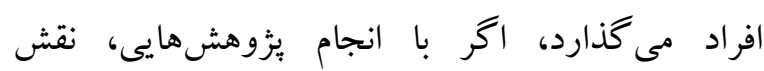
واسطهاى يا تعديل كنندهاى متغيرهايى همجِون متغيرهاى فوق كه در تسكين و يا كاهش شدت علائم و رشد بِ يس تصدين از آسيب مؤثر باشند، معلوم شود، دست اندركاران بهداشت روانى را در تدوين برنامهها و درمانهايى كه به مداخله زود هنگام كمكك كند و از آسيبهاى شديدتر جلو گيرى كند و احتمال رفتارهاى مخرب را در دوران بزركسالى كاهش دهد، يارى خواهد كرد. با توجه به موارد ذكر شده، سؤال يثزوهش حاضر اين است كه آيا آميختخى شناختى، تحمل آشفتگى و دلسوزى به خود در ييشبينى بهبودى از آسيب افراد آزار ديده در دوران كود كى نقش دارد؟

روش

يثزوهش حاضر از نوع توصيفى - همبستكى بود. جامعه آمارى اين بثزوهش را تمامى افراد آزارديده بالاتر از ها

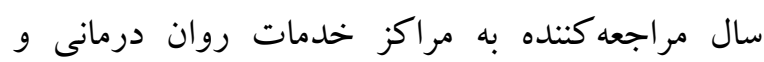
مشاوره شهر شيراز در نيمه اول سال وهبا تشكيل دادند.

7. Neff \& McGeheea
باكر، لانت'، 11 ·r)، اختلال وسواسى-اجبارى (ريومن،

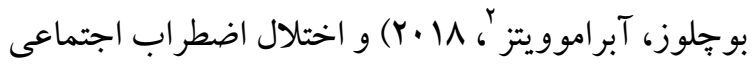

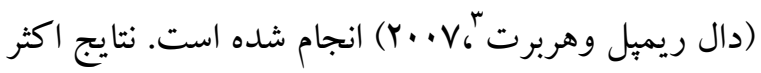
اين يزوهشها از نقش واسطهاى آميختكى شناختى در بروز و تشديد اختلالهاى روان شناختى حمايت مى كند. يكى ديخر از متغيرهاى مرتبط با رشد بِ بس آسيبى، تحمل آشفتكى است. تحمل آشفتخى به توانايى تجربه و تحمل موقعيتهاى روانشناختى منفى اطلاق مى مردد. يثزوهشخران و درمانكران علاقه داشتهاند كه نقش تحمل آشفتخى را كه عاملى مخالف براى استرسهاى درونى (مانند هيجانات منفى، احساسات ناخوشايند جسمانى) در انواع مختلف آسيبهاى روانى است، تشريح كنند

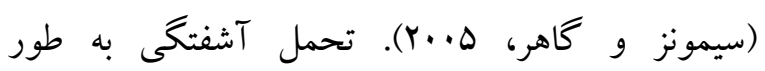
فزايندهاى، به عنوان يكك ساختار مهم در رشد بينشى جديد درباره شروع و ابقاء آسيبهاى روانى و همجينين بيشخيرى و درمان مشاهده شده است. بسيارى از اين كزارشهاى بر مفهوم مجزاى تحمل آشفتكى در ميان افراد مبتلا و يا در معرض خطر براى آسيبهاى روانى تمركز داشتهاند (هرناندز، دانداسكارا، آرلينگوس، شارما،

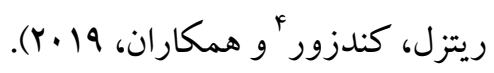
يكى ديخر از متغيرهايى كه مىتواند به عنوان يكك عامل حفاظتى ساز گاركننده در برابر حوادث تروماتيك و و آسيب هاى روانى عمل كند و در بهبودى از آسيبهاى ناشى از تروما نقش دارد (بلوث و روبرسون، گايلورد،

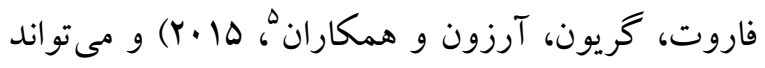

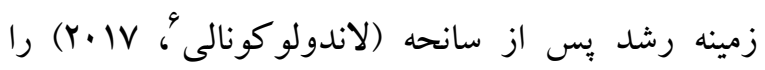

\footnotetext{
1. Cox Motl, Bakker, \& Lunt

2- Reuman, Buchholz, \& Abramowitz

3 - Dalrymple \& Herbert

4- Hernandez, Daundasekara, Arlinghaus, Sharma, Reitzel, Kendzor

5 - Bluth, Roberson, Gaylord, Faurot, Grewen \& Arzon

6. Londoño Connally
} 
بدرفتارى را مورد سؤال قرار مىدهد: ا. سوء استفاده هيجانى Y. سوء استفاده جسمى لr. سوء استفاده جنسى F. غفلت عاطفى ه. غفلت جسمى. اين مقياس شامل ب گويه براى جستجوى گزارش تروماى منفى كاذب است. مطالعات يايايى و روايى با نمونهاى بالينى و غير بالينى

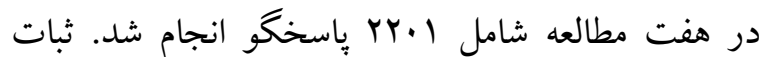
درونى آلفاى كرونباخ هذ/. براى كل مقياس بسيار رضايت بخش بود. اعتبار سازه قوى بود، گروههاى بالينى سطوح بالاترى از سوء استفاده و غفلت را نسبت به نمونههاى غير بالينى گزارش كردند (برنشتاين و فينك،

.$(1991$

\section{مقياس آميختكى شناختى ' (CFQ): اين مقياس توسط}

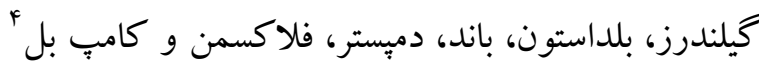
ساخته شده است كه داراى V سؤال بوده و به (Y P F) شيوه ليكرتى از هيج وقت درست نيست تا كاملاً درست است، روى يكك مقياس V درجهاى از يكك تا V نمره كذارى مىشود. نمره كل اين يرسشنامه در دامنه قرار مى گيرد. نمرات بالاتر در اين مقياس، آميختكى شناختى بيشتر را منعكس مى كند. گيلندرز و همكاران

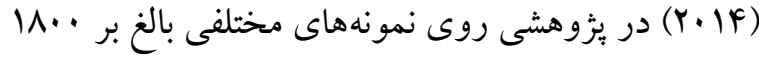
نفر، شواهد اوليه خوبى از ساختار عاملى، اعتبار، ثبات زمانى و روايى افتراقى و حساسيت به درمان نشان دادند.

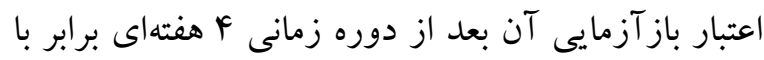

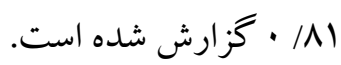

مقياس تحمل آشفتكى " (DTS): اين مقياس خودسنجى

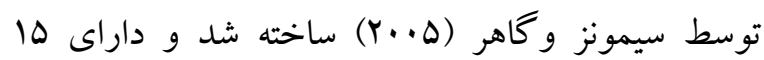
سؤال و \& زير مقياس است. زير مقياسهاى آن عبارتاند

3 - Cognitive Fusion Questionnaire

${ }^{4}$ - Gillanders, Bolderston, Bond, Dempster, Flaxman \& Remington

5- Distress Tolerance Scale
با توجه به اينكه حداقل حجم نمونه در تحقيقات همبستكى ، ب نفر به ازاى هر متغير بيشبين است

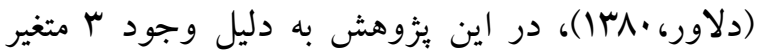
ييشبين •ه نفر كفايت مى كرد؛ اما جهت افزايش اعتبار 19.19 بيرونى بثزوش،، تعداد •19 نفر انتخاب شدند. تعداد نفر (4 ا نفر زن و 91 نفر مرد) از اين افراد به روش نمونه كيرى در دسترس از جامعه آمارى فوق انتخاب و در يثزوهش شركت داده شدند. قبل از يثزوهش، فرم رضايت

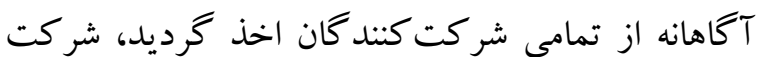
آزمودنىها در اين بثزوهش كاملاً داوطلبانه و گمنام بود و در هر لحظه مىتوانستند از يثوهش خارج شوند. ملاكك ورود به يُزوهش شامل رضايت آكاهانه جهت شركت در يثزوهش و سواد خواندن و نوشتن و ملاكك خروج عبارت بود از عدم تمايل به شركت در ئزوهش و تشخيص اختلالات روانشناختى ديخر. بعد از تمام فرايند اجرا، دادهها با استفاده از روش ضريب همبستخى ييرسون و ركرسيون جند گانه و با استفاده از نرم افزار SPSS نسخه r r مورد تجزيه و تحليل قرار كرفت.

برسشنامه ترومايى دوران كودكى' (CTQ): اين مقياس

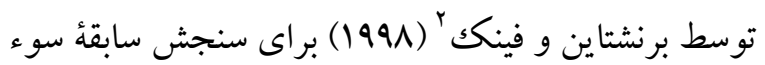
استفاده و غفلت از كودكك براى نوجوانان بال ساله و بالاتر و بزركسالان ساخته شده است. اين مقياس

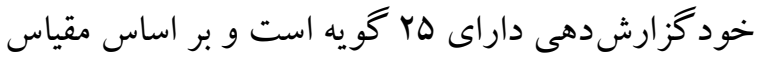
ه درجهاى ليكرت (هركز="•، هميشه=ه) نمره كذارى

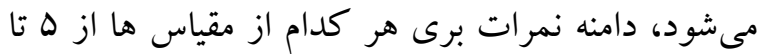

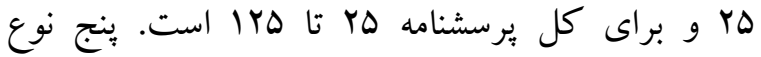

\footnotetext{
1. Childhood Trauma Questionnaire

2 - Bernstein \& Fink
} 
تغييرات خود ادراكى مرتبط با تجربه آسيبزا ساخته شده است. اين برسشنامه شامل الr عبارت در مقياس ليكرت با دامنه صفر (من اين تغيير را به عنوان نتيجه بحران نمىدانم) تا ينج (من اين تغيير را به ميزان خيلى زيادى به لهيه عنوان نتيجه بحران مىدانم) تشكيل شده است. اين برسشنامه داراى هـ زير مقياس است كه عبارتاند از: شيوه هاى جديد (ه ماده)، برقرارى ارتباط با ديخران (V ماده)، قدرت شخصى (F ماده)، ارزش زندكى (r ماده) و تغيير معنوى (Y ماده). نمرات مقياسها به وسيله جمع نمرات عبارت در هر عامل حساب مىشود. نمره نهايى مقياس براى مقياس رشد بس از آسيب قابل محاسبه است. در

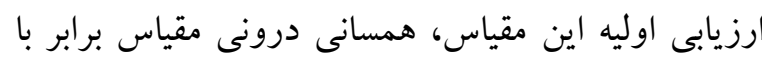

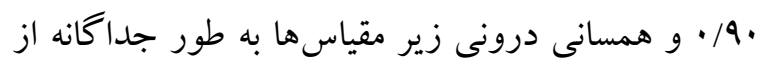

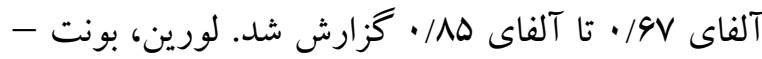

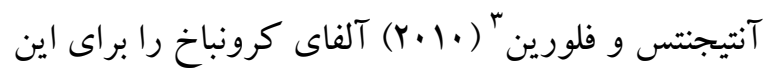

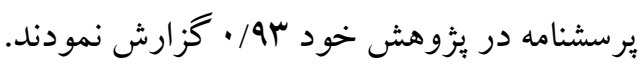

يافتهها

يافتهاى جمعيت شناختى بيانكر اين است كه از بين

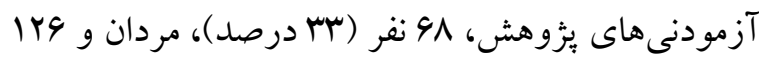
نفر (9V درصد)، زنان بودند. با دامنه سنى از 19 تا .F سال

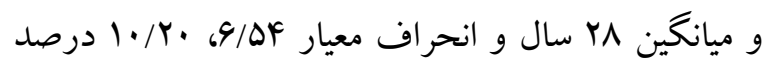

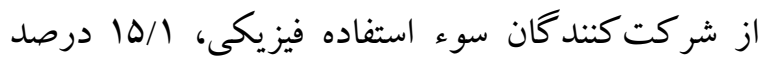

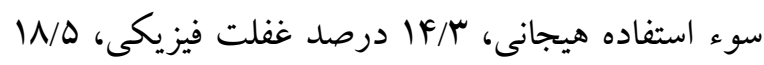
درصد غفلت هيجانى و 9/11 درصد سوء استفاده جنسى را تجربه كرده بودند. يافتهاى توصيفى مربوط به ميانگين و انحراف استاندارد نمرات شركت كنندكان در متغيرهاى آميختخى شناختى، تحمل آشفتخى، دلسوزى به خود و رشد يس آسيبى در جدول ا ارائه شده است.

${ }^{3}$ - Lelorain, Bonnaud-Antignac \& Florin
از تحمل، جذب، ارزيابى و تنظيم كه روى يكك مقياس ينج درجهاى (1) كاملاً موافق، (Y) اندكى موافق، (Y) به (Y) يكك اندازه موافق و مخالف، (F) اندكى مخالف، (ه) كاملاً مخالف نمره گذارى مىشوند، نمرات بالاتر نشانگر

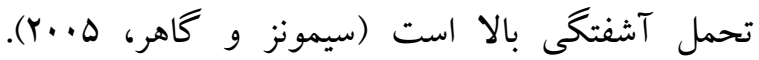

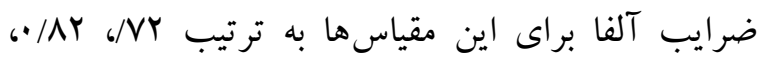

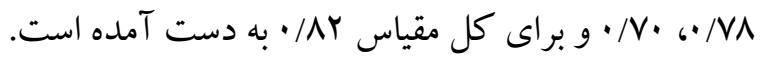
مقياس دلسوزى به خود' (SCSS): اين ابزار يك مقياس

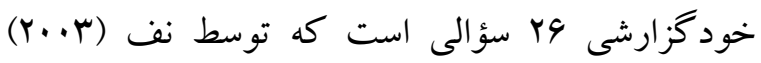

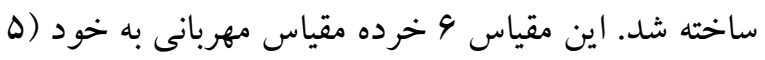

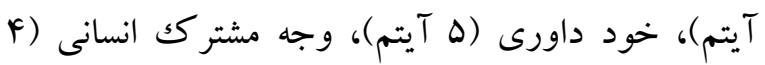
آيتم)، انزوا (F آيتم)، ذهن آكاهى (F آيتم) و همدردى يا همانندسازى بيش از حد (F آيتم) را در بر مى كيرد. آزمودنىها به سؤالات اين برسشنامه در مقياس ليكرت

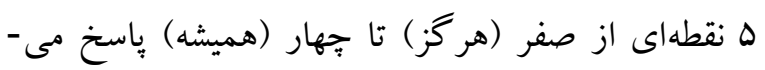

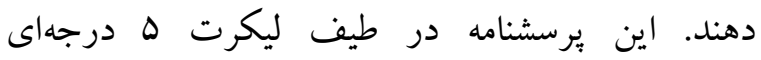
(1=تقريباً هر زز؛ ه=تقريباً هميشه) نمره كذارى مىشود. ميانگين نمرات اين 4 خرده مقياس نيز با احتساب نمرات معكوس نمره كلى دلسوزى به خود را به دست مي دهد. يُزوهشهاى مربوط به اعتباريابى مقدماتى اين برسشنامه نشان دادهاند كه همه اين 4 خرده مقياس همبستكى مروطى درونى بالايى دارند و تحليل هاى عاملى تأييدى نيز نشان دادهاند كه عامل مجزاى دلسوزى به خود اين همبستگى درونى را تبيين مىنمايد. ثبات درونى اين برسشنامه در

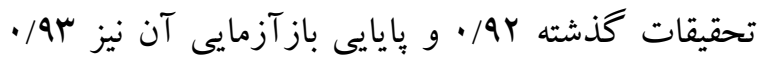

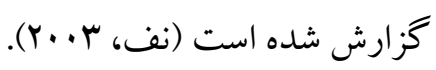
يرسشنامه رشل پِ از آسيب ' (PTGI): اين برسشنامه در سال 1999 توسط تدسجى و كالهون به منظور ارزيابى

1- Self-compassion scale

${ }^{2}$ - Posttraumatic growth inventory 
جدول 1 ميانكين و انحراف معيار نمرات آزمودنىها در كودكى آزارى، آميختكى شناختى، تحمل آشفتعى، دلسوزى به خود، رشد بِ إس از سانحه

\begin{tabular}{|c|c|c|c|}
\hline انحراف معيار & ميانكين & & متغير ها \\
\hline$\cdot / \Delta \cdot r$ & $1 \cdot / r$ & آزار فيزيكى & \multirow{5}{*}{ كودكى آزارى } \\
\hline • TMY & $10 / 1$ & آزار هيجانى & \\
\hline$\cdot / Y_{F}$ & $\mid F / r$ & غفلت فيزيكى & \\
\hline.$/ 10$ & $\mid N / \Delta \Lambda$ & غفلت هيجانى & \\
\hline.$/ 499$ & $9 / \backslash \wedge F$ & آزار جنسى & \\
\hline$\cdot / A \Delta F$ & WI/Vr & آميختخى شناختى & \multirow[t]{2}{*}{ آميختكى شناختى } \\
\hline$\cdot / 4 \cdot 4$ & $\mid F / T \Delta$ & تحمل & \\
\hline - MGY & G/AY & 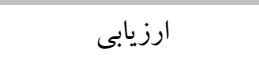 & \multirow{5}{*}{ تحمل آشفتگى } \\
\hline - /TOF & $V / 91$ & جذب & \\
\hline.$/ Y 4$. & $9 / 19$ & تنظيم & \\
\hline - & $\Lambda / F \Lambda$ & مهربانى به خود & \\
\hline$\cdot / \mu \cdot \Lambda$ & $V / .9$ & انسانيت عمومى & \\
\hline - RAI & N/YF & ذهن آكاهى & \multirow{5}{*}{ دلسوزى به خود } \\
\hline.$/ 191$ & $10 / \Delta \Delta$ & خود داورى & \\
\hline .119 & $\mid r / \Delta \Delta$ & انزوا & \\
\hline$\cdot \pi$ & Ir/TG & همدردى بيش از حد & \\
\hline$\cdot / V \Delta V$ & $r \cdot / r q$ & دركى تو انايى خود & \\
\hline - /OrR & $19 / 4$. & تغيير در اهداف & \multirow{3}{*}{ رشد پس از سانحه } \\
\hline$\cdot / R V r$ & $1 / \cdot 9$ & صميميت با ديخران & \\
\hline$\cdot / Y \wedge \Lambda$ & $9 / \cdot 1$ & تلاش براى حفظ روابط & \\
\hline
\end{tabular}

نتايج حاصل از جدول ا بيانگر آن است كه ميانگين مؤلفه تلاش براى حفظ روابط مربوط به متغير رشد بِ از

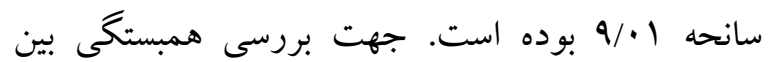

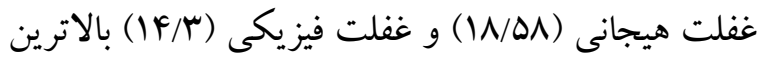

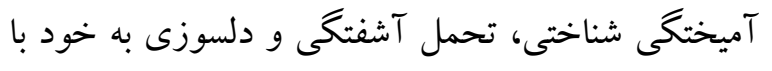
ميزان را در مؤلفه كودك آزارى دارا هستند. ميانگين رشد بـ آسيبى از روش همبستخى بيرسون استفاده

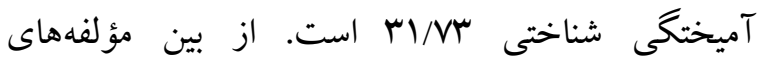

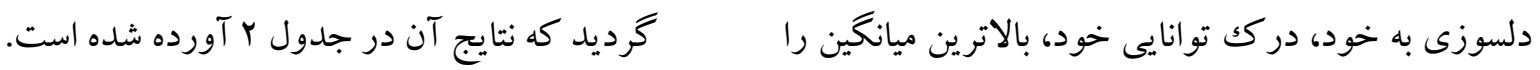
به خود اختصاص داده است (q//.Y). در نهايت ميانگين

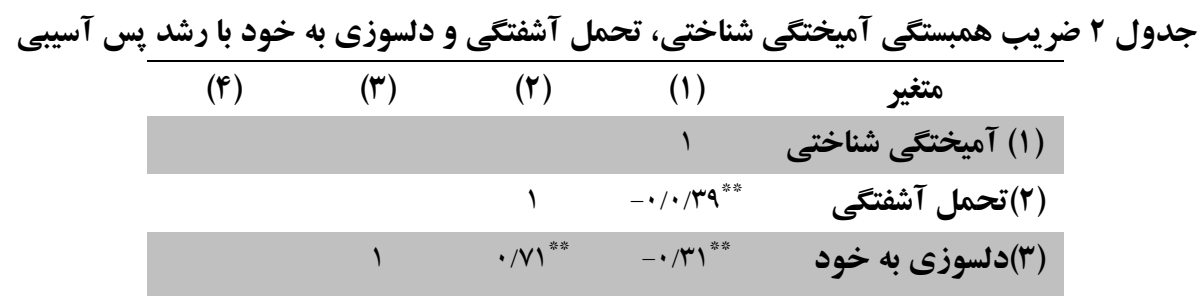




\begin{tabular}{|c|c|c|c|c|}
\hline 1 &.$/ 9 Y^{* * *}$ & $\cdot / \pi 9^{* * *}$ & $-\cdot / \Gamma 4^{*}$ & (F)رشد پِ آسيبى \\
\hline
\end{tabular}

مقدماتى استفاده گرديد. مقادير مربوط به تولارنس (بزرگكتر از 1+/) و وى آى اف (كمتر از • (1) نشانگر

مستقل بودن خطاها بوده است. همجنين جهت بررسى نرمال بودن توزيع متغير ملاكك از آزمون كولموكروف- بون

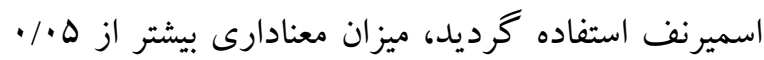
بود كه نشانكر نرمال بودن توزيع بود. جدول اه، ضرايب

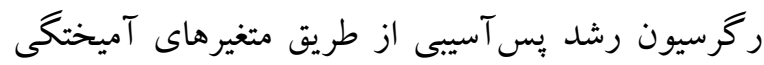
شناختى، تحمل آشفتگى و دلسوزى به خود را نشان مىدهد كه نتايج آن در زير ارائه مى گردد.
نتايج حاصل از جدول r بيانگر اين است كه بين آميختخى شناختى و رشد يُ آسيبى ارتباط منفى معنادار

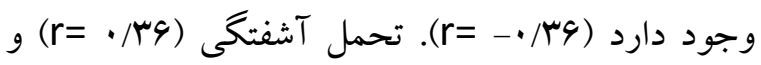

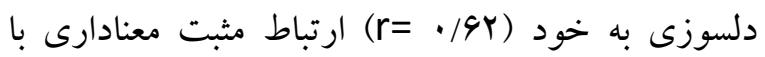
رشد بس آسيبى داشتند. جهت بررسى نقش آميختكى شناختى، تحمل آشفتكى و دلسوزى به خود در رشد

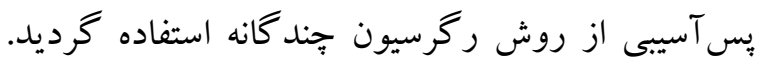
جهت اطمينان از عدم تخطى از مفروضههاى نرمال بودن، خطى بودن، هم خطى و يكسانى براكندگى از تحليل

\begin{tabular}{|c|c|c|c|c|c|c|c|c|c|c|c|}
\hline واريانس & تولارنس & معنىدارى & $\begin{array}{c}\text { آزمون } \\
\text { t }\end{array}$ & ر ركرسيون & $\begin{array}{c}\text { خطاندارد } \\
\text { B }\end{array}$ & 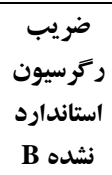 & معنى دارى & $\mathbf{F}$ & تعريين & 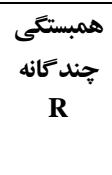 & متغيرهاى ييشبين \\
\hline & & & & & & & $\cdot / . .1$ & $r q / \cdot \Delta \wedge$ & $\cdot|4|$ & .1949 & مقدار ثابت \\
\hline $1 / \Delta \cdot r$ & .1990 &.$/ 91$ &.$/ .11$ & $/ \cdot r$ & . / $\Delta \Delta r$ & $\cdot / . r$ & & & & & آميختكى شناختى \\
\hline $1 / r \cdot r$ & - ART &.$/ .1$ & $r / F \cdot \Lambda$ & $\cdot / \backslash 11$ & ./TYF & $\cdot / 499$ & & & & & تحمل آشفتكى \\
\hline $1 / 4+1$ &.$/ 999$ &.$/ \cdot 1$ & G/NIr & $\cdot / \Delta \Delta \Lambda$ & וזו/. & . /^९. & & & & & دلسوزى به خود \\
\hline
\end{tabular}

يّ آسيبى ارتباط منفى معنادار وجود دارد. در تبيين اين

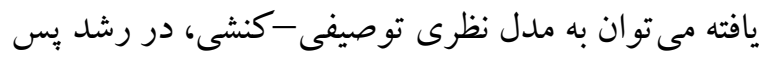

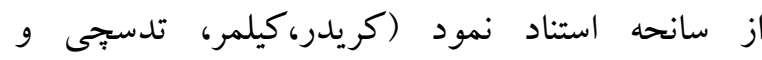

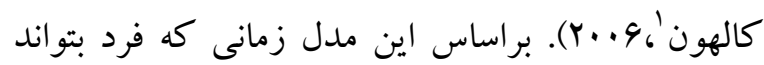
افكار منفى خود را بعد از حوادث تروماتيك كنترل نمايد، زمينه رشد بِ از از سانحه در وى فراهم

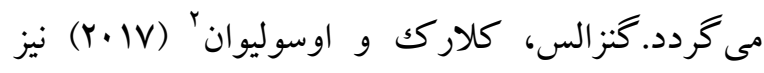
معتقدند نحوه بردازش شناختى بر رشد يس از سانحه مؤثر است. بر اساس مدلهاى مبتنى بر بِذيرش و

1. Cryder, Kilmer, Tedeschi \& Calhoun

${ }^{2}$ - Gonzalez, Chowdhury, Dutcher, Dick, Kendler. \& Amstadte
نتايج جدول r نشان مىدهد الF درصد از كل واريانس رشد يسآسيبى به وسيله دلسوزى به خود و تحمل آشفتخى تبين مىشود و آميختخى شناختى قادر به بيشبينى رشد بِ آسيبى نيست. يُزوهش حاضر با هدف بررسى نقش آميختخى شناختى،

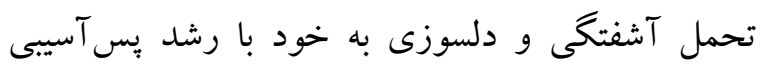
افراد آزاد ديده در دوران كودكى انجام شد. نتايج حاصل

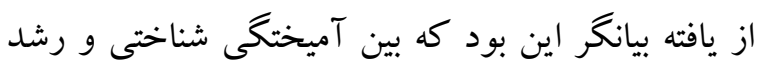




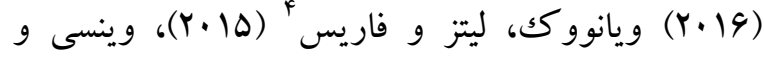

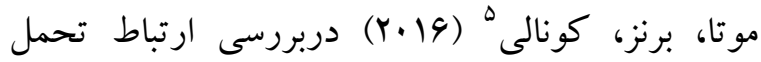
آشفتگى با اختلال استرس بس از سانحه است. همجرنين زو، وو و زن (Y. IV) نشان دادند كه نحوه كنترل و تنظيم هيجان ارتباط مستقيمى با رشد پِ إن از سانحه دارد. تحقيقات نشان دادهاند كه آزارهاى دوران كودكى با. تحمل آشفتخى بايين در بزر گسالى ارتباط دارد (برنز و

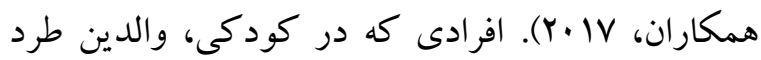
كننده يا كنترلكننده داشتهاند، در اوايل بزر كسالى شكايات جسمانى مرتبط با بر يشانى و آشفتكى و همجينين شكايات عصب شناختى را تجربه كردهاند (كروتنى و

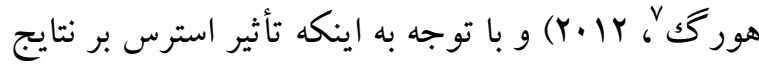
بالينى به سطح تحمل بريشانى فرد بستخى دارد (كليريخى، ارونسون، اسميت؛ علائمى را با ميزان تحمل آشفتگى هِايين مرتبط دانست. نتايج تحليل رگرسيون نشان داد كه FF درصد از كل واريانس رشد بس آسيبى به وسيله تحمل آشفتخى تبيين مىشود. تحمل آشفتخى عاملى مهم در شروع و تداوم

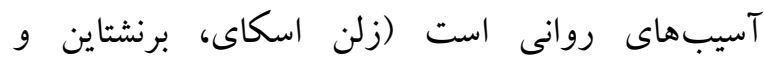

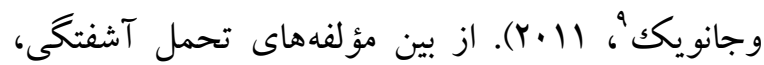
تحمل توانست اختلال استرس بِ إز از سانحه را در افراد آزارديده بيشبينى كند و همجنين مؤلفه جذب قادر به يِيشبينى رشد يسآسيبى بود. تحمل، ميزان توانايى فرد براى تحمل بريشانى را اندازهگيرى مى كند (سيمونز و كاهر، ه ·.Y). در تبيين اين يافته مىتوان بيان كرد كه هر جه ميزان تحمل فرد در مقابل مصائب و سختىهاى

4- Vujanovic, Litz \& Farris

5 - Vinci, Mota, Berenz \& Connolly

${ }^{6}$ - Zhou, Wu \& Zhen

7. Courtney \& Hoerge

8 - Cleirigh, Ironson \& Smits

9-Zvolensky, Bernstein \& Vujanovic
ذهن آكاهى، آميختكى شناختى يكى از فرايندهاى واسطه اى است كه در اكثر اختلالهاى روانشناختى نقشى ستى كليدى و بنيادين ايفا مى كند (هايز و همكاران، Y Y.Y). تحقيقات كيلاندرز و همكاران (ها +Y) نشان داده است كه آميختخى شناختى از عوامل تأثير گذار در كيفيت زندگى افراد است و نقش مهمى در بروز و تداوم اختلالهاى روانى دارد. افرادى كه آميختكى شناختى در آنها بالاست بيشتر احتمال دارد كه به اختلال استرس

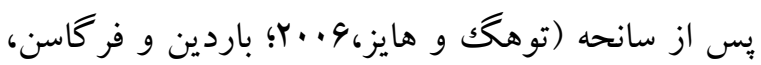

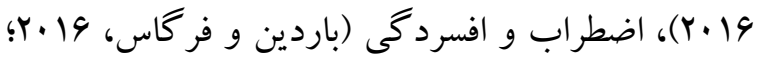

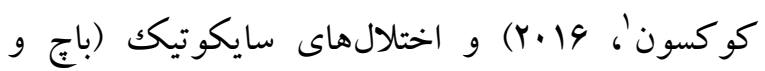

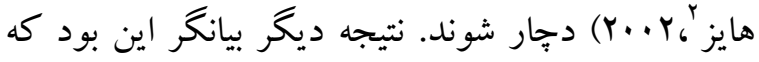
آميختكى شناختى قادر به يِيش بينى رشد يس آسيبى نبوده است. يكك تبيين در ارتباط با عدم معنادارى بيش بينى رشد بِ آسيبى از طريق آميختخى شناختى اين است كه در آميختخى شناختى فرد به طور افراطى درگير افكارش مىشود، به طورى كه اين افكار بر رفتار وى مسلط مى -

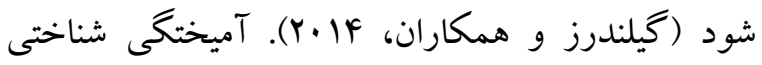
شديداً با اجتناب رفتارى، بريشانى و اضطراب و ساير نتايج نامساعد در طيف وسيعى از اختلالهاى جسمى و روانى مشخص مىشود كه مىتواند در سببشناسى و ماند كارى اختلالهاى اضطرابى نقش مهمى ايفاء كند و متقابلاً با رشد يس آسيبى ارتباط منفى معنادارى داشته

يافته دوم يزّوهش بيانكر اين بود كه تحمل آشفتكى با بهبودى از آسيب افراد آزارديده ارتباط دارد. اين يافتهها همسو با تحقيقات ويانوو ك،، راتناياكاه، آمادور و اسميتز

\footnotetext{
1- Cookson

2- Bach \& Hayes

3. Vujanovic, Rathnayaka, Amador \& Schmitz
} 
خو اهد داشت كه از تابآورى و دلسوزى به خود بيشترى

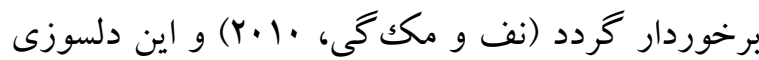
به خود به عنوان عاملى حفاظتى در برابر اين آسيبها عمل نمايد (زلر و همكاران، || ·r) و از ابتلا به اختلال

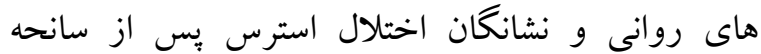

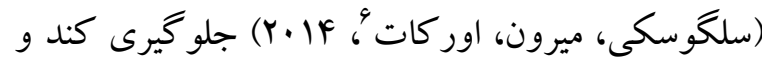
حتى مشكلات تنظيم هيجان را كاهش دهد (وتز و دير،||(Y). افرادى كه دلسوزى به خود بالايى دارند در شرايط استرس از راهبردهاى انطباقى كار آمدترى براى كنار آمدن با رويدادهاى منفى زندكى استفاده مى كنند و

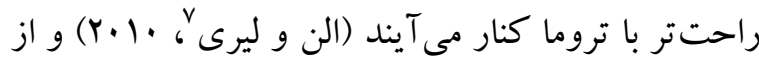
سلامت هيجانى بالاترى برخوردارند (بلوث و روبرسون،

$(Y \cdot 10$

همجنين، دلسوزى به خود در بيشبينى بهبودى از آسيب افراد آزارديده نقش دارد. نتايج تحليل رگرسيون نشان داد كه هاF درصد از كل واريانس رشد بِ از سانحه بهوسيله دلسوزى به خود تبين مىشود. درتبيين يافتهاى حاصل از رگرسيون در خصوص اين فرضيه مىتوان نتيجه گرفت كه از آنجايى كه براساس ديدگاه نف، دلسوزى به خود مىتواند نقش محافظتى در برابر آسيبهاى روانى داشته باشد و به كاهشهايى در آسيبشناسى روانى، شامل افسردگى و اضطراب

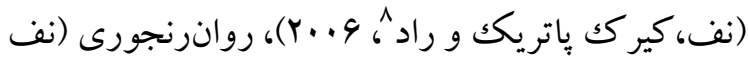

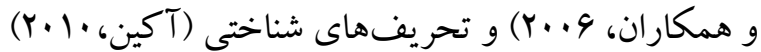
منجر شود، مىتواند در سلامت روان و بهزيستى روانشناختى نقش داشته و زمينه رشد پس از سانحه (ميجزل

${ }^{6}$ - Seligowski, Miron, Orcutt

7- Allen \&Leary

${ }^{8}$ - Neff, Kirkpatrick \& Rude

${ }^{9}$ - Mitchell
زندگى از جمله آزارهاى دوران كودكى بيشتر باشد، ميزان بروز اختلال هاى روانى مانند اختلال استرس يس از سانحه و اضطراب و افسردكى كمتر خواهد بود

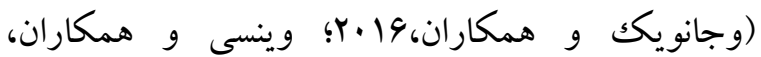

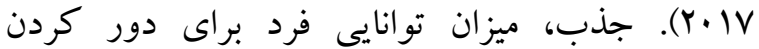
احساس آشفتكى از خود، براى متمركز كردن توجه را

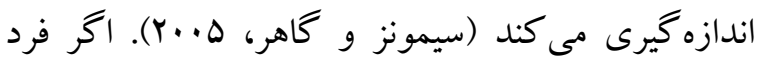
بتواند توجه خود را متمركز كند و به دور از احساس يريشانى به راههاى مثبت حل مشكل بيانديشد و تمركز خود را بر برنامهريزى مؤثر براى نحوه كنار آمدن و اداره كردن مشكل صرف كند، اين روش به عنوان يك راهبرد ساز گار مىتواند رشد يس از سانحه را افزايش دهد

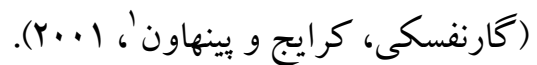
يافته ديخر بثزوهش حاضر اين است كه دلسوزى به خود با بهبودى از آسيب افراد آزارديده ارتباط دارد. اين يافتها همسو با تحقيقات نف (r...Y)، لرى، تيت، آدامز،

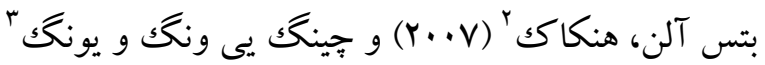

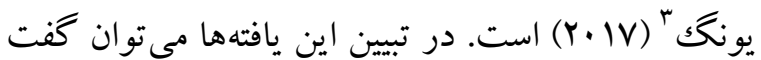
طبق تحقيقات، افرادى كه در كودكى مورد بدرفتارى قرار مى گيرند دلسوزى به خود پايينترى دارند و در بزر گسالى بيشتر دجار آشفتگى هاى روانى (تاناكا، وكرل،

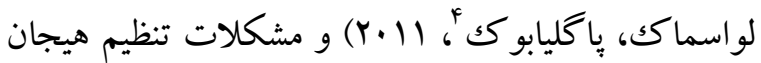
هيجان (وتز و دير، لى، وكرله، (1) اكر متغيرهايى مانند حمايت مادرى، سبككهاى دلبستكى، رونى كاركرد خانواده و حمايتهاى اجتماعى كه بيشبينى -

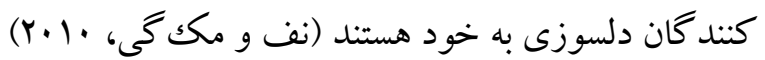
به صورت مثبت در ميان آيند، شخص اين شانس را

1. Garnefski, Kraaij \& Pinhoven

${ }^{2}$ - Leary, Tate, Adams, Batts Allen \& Hancock

3 - Ching, Yee, Wong \& Yeung

4- Tanakaa, Wekerle, Lou Schmuckc, Paglia-Boak

5 - Vettese, Dyer, Li \& Wekerle 
محدوديت هايى است. از جمله محدوديت هاى يزوهش

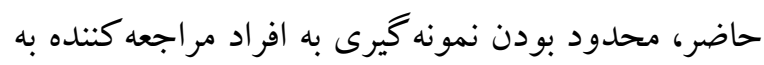
ץ مركز رواندرمانى، ناتوانى در كنترل اختلالهاى

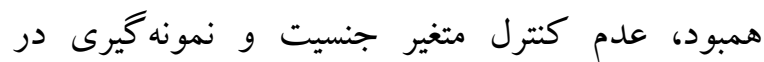
دسترس بود، بدين منظور بيشنهاد مىشود در مطالعات آتى اختلالهاى همبود با تجربه كودكك آزارى كنترل شود، از تعداد نمونه بيشترى استفاده شود تا تعميم نتايج با اطمينان بيشترى امكانيذير باشد. عامل جنسيت در يثزوهشهاى آتى مد نظر قرار كيرد و موضوع رشد بس آسيبى در دو جنس زن و مرد به طور جداگانه مورد بررسى قرار گيرد.

\section{سياسگز ارى}

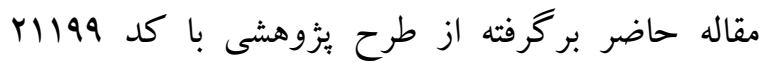
مصوب دانشگاه محقق اردبيلى است. بدين وسيله نويسندكان بر خود لازم مىدانند تا از تمامى شركت كندكان محترمى كه در كل فرايند تحقيق همكارى

$$
\text { كردند، تقدير و تشكر نمايند. }
$$

\section{References}

Akin U. (2014). The predictive role of self of selfcompassion on social Well-being in Turkish university students. Suvremena psihologija, 1, pp. 53-62.

Allen AB, \& Leary MR. (2010). Self-compassion, stress, and coping. Social and personality psychology, 4(2), pp. 107-118.

Bach P, Hayes SC. (2002). The use of acceptance and commitment therapy to prevent the rehospitalization of psychotic patients: A randomized controlled trial. Joumal of Consultant Clinical Psychology, 70(5), pp. 1129-1139.

Bardeen JR, Fergus TA. (2016). The interactive effect of cognitive fusion and experiential avoidance
كمك مى كند تا موقع مواجهه با بحرانهاى زندگى از طريق مشاهده افكار و احساسات مرتبط با آن رويدادهاى منفى و نه با انكار يا واكنش بيش از حد نشان دادن، با آن حوادث مقابله كنند. افرادى كه دلسوزى به خود بالايى دارند يكى رويكرد متعادل براى بررسى تجربيات دردناكك خود و درد و رنج حاصل از آنها در بيش مى بـ برنى كيرند. همجنين افراد دلسوز به خود به دليل برخوردارى از تجربه مشترك انسانى، بيشتر مايل به افشاى تجربيات منفى خود هستند و به اين طريق از حمايت سايرين برخوردار مىشوند كه اين موضوع به بهتر شدن روابط آنها با سايرين كمكك مى كند و ارتباط مؤثر با ديخران از مؤلفه هاى رشد بوده و در تسهيل رشد يس از سانحه مؤثر

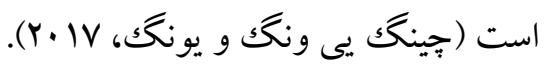

\section{نتيجه كيرى}

يُزوهش حاضر نشان داد كه بين رشد يس آسيبى با تحمل آشفتگى و دلسوزى به خود رابطه مثبت معنادار و با آميختكى شناختى رابطه منفى معنادار داشت. همجِين نتايج تحليل رگرسيون نشان داد تحمل آشفتخى و دلسوزى به خود قادر به بِيشينى رشد بِس آسيبى افراد

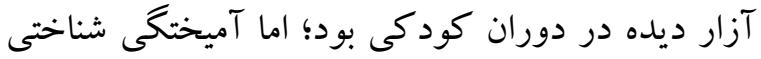
قادر به بيشينى رشد بس آسيبى نبود. به عبارتى ديكر، مى توان نتيجه گرفت افرادى كه آميختكى شناختى پيايين تر، تحمل آشفتگى بالاتر و دلسوزى به خود بيشترى دارند، در مقايسه با افراد با آميختخى شناختى بالا، تحمل

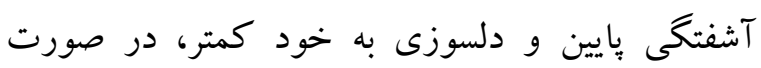
مواجهه با آزار و بدرفتارىهاى كودكى از بهبودى

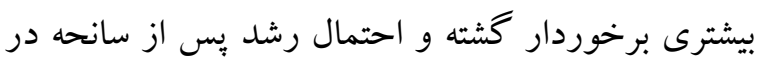
آنها بالاتر است. در پيايان ذكر اين نكته لازم است كه هماند تمامى يُزوهشها، يُزوهش حاضر نيز داراى 
on anxiety, depression, stress and posttraumatic stress symptoms. Joumal of Contextual Behavioral Science, 5(1), pp.1-6.

Basharpoor S. (2015). Character traits: theory and test. Tehran: Savalan publication. [In Persian].

Bemstein DP, Fink L. (1998). Childhood Trauma Questionnaire: A Retrospective Self-Report. (CTQ). Harcourt Brace \& Company, Child psychiatry-68 pages.

Bluth K, Roberson PNE, gaylord SA, Faurot KR, Grewen KM, Arzon S. Girdler SS. (2015). Does Self-compassion Protect Adolescents from Stress? Joumal of child and family studies, 25(4), pp.1098-1109.

Burns EE, Fischer S, Jackson JL, \& Harding HG. (2012). Deficits in emotion regulation mediate the relationship between childhood abuse and later eating disorder symptoms. Child abuse $\&$ neglect, 36(1), pp. 32-39.

Ching Yee Wong C, Yeung N. (2017). Selfcompassion and Posttraumatic Growth: Cognitive Processes as Mediators. Mindfulness, 8(4),pp. 1078-1087.

Cicchetti D, \& Garmezy N. (1993). Prospects and promises in the study of resilience. Development and Psychopathology, 5, pp. 497-502.

Cleirigh CY, Ironson G, Smits JA. (2007). Distress Tolerance Moderate the impact of Major Life Events on Psychosocial Variables and Behaviors important in the Management of HIV. behavior therapy, 38, pp. 314-323.

Cloitre M, Miranda R, Stovall-McClough KC, Han H. (2005). Beyond PTSD: Emotion regulation and interpersonal problems as predictors of functional impaiment in survivors of childhood abuse. Behavior Therapy, 36(2), pp. 119-124.

Cookson C. (2016). The role of cognitive fusion and experiential avoidance in anxiety and depression. Submitted in partial fulfilment of the requirements for the degree of Doctor of Clinical Psychology (DClinPsy), Royal Holloway, University of London.

Courtney N, Hoerge BM. (2012). Parental ChildRearing Strategies Influence Self-Regulation,
Socio-Emotional Adjustment, and Psychopathology in Early Adulthood: Evidence from a Retrospective Cohort Study. Joumal of personality and Individual Differences, 52(7), pp. 800-805.

Cox DW, Motl TC, Bakker AM, Lunt RA. (2018). Cognitive fusion and post-trauma functioning in veterans: Examining the mediating roles of emotion dysregulation. Journal of Contextual Behavioral Science, 8, pp.1-7.

Cryder CH, Kilmer RP, Tedeschi RG, Calhoun LG. (2006). An exploratory study of posttraumatic growth in children following a natural disaster. American Joumal of Orthopsychiatry, 76(1), pp. 65-69.

Dalrymple KL, Herbert JD. (2007). Acceptance and commitment therapy for generalized social anxiety disorder. A pilot study.US National Library of Medicine National Institutes of Health. Behavioral Modification, 31(5), pp. $543-468$

Fairbank JA, Fairbank DW. (2009). Epidemiology of child traumatic stress. Cument Psychiatry Reports, 11(4),pp. 289-295.

Follette V, Palm KM, Pearson AN. (2006). Mindfulness and trauma: Implications for treatment. Joumal of rational-emotive and cognitive-behavior therapy, 24(1), pp. 45-61.

Garnefski N, Kraaij V, Pinhoven P. (2001). Negative life events, cognitive emotion regulation and emotional problems. Personality and Individual Differences, 30(8), pp. 1311-1327.

Gillanders DT, Bolderston H, Bond FW, Dempster M, Flaxman PE, Campbell L, \& Masley S. (2014). The development and initial validation of the Cognitive Fusion Questionnaire. Behavior Therapy, 45(1), pp. 83-101.

Gonzalez E, Chowdhury N, Dutcher K, Dick DM, Kendler KS, \& Amstadter A. (2017). A Multimodal Study of Childhood Trauma and Distress Tolerance in Young Adulthood. Joumal of Aggression, Maltreatment \& Trauma, 2(52), pp. 1-16.

Hayes SC, Strosahl KD, Wilson KG. (2012). Acceptance and commitment therapy: the 
process and practice of mindful change $\left(2^{\text {nd }}\right.$ ed). New York: Guilford.

Heckman CJ, \& Westefeld JS. (2006). The relationship between traumatization and pain: What is the role of emotion? Joumal of family violence, 21(1), pp. 63-73.

Hernandez DC, Daundasekara SS. Arlinghaus KR, Sharma AP, Reitzel LR, Kendzor DE, \& Businelle MS. (2019). Fruit and vegetable consumption and emotional distress tolerance as potential links between food insecurity and poor physical and mental health among homeless adults. Preventive medicine reports, 14,pp.100824.

Hund AR, \& Espelage DL. (2006). Childhood emotional abuse and disordered eating among undergraduate females: Mediating influence of alexithymia and distress. Child abuse \& neglect, 30(4), pp. 393-407.

Johnston M, Foster M, Shennan J, Starkey NJ, Johnson A. (2010). The effectiveness of an acceptance and commitment therapy self-help intervention for chronic pain Clinical Joumal of Pain, 26(5), pp. 393-402.

Leary MR, Tate EB, Adams CE, Batts Allen A, \& Hancock J. (2007). Self compassion and reactions to unpleasant self-relevant events: The implications of treating on self kindly. Journal of personality and social psychology, 92(5), pp. 887-904.

Lelorain S, Bonnaud-Antignac A, \& Florin A. (2010). Long term postraumatic growth after breast cancer: Prevalence, predictors and relationships with psychological health. Journal of Clinical Psychology in Medical Settings, 17(1), pp. 14-22.

Londoño Connally M. (2017). The role of selfcompassion in postrumatic growth. Dissertation Prepared for the Degree of doctor of philosophy university of north texas.

Mitchell E. (2017). Postraumatic Growth, the Physically Active Body, and SelfCompassion. Dissertation. Doctor of Philosophy (Ph.D). Oregon State UniversityCiteable URL.
Neff K. (2003). The Development and Validation of a Scale to Measure Self-Compassion. Self and identity, 2(3), pp. 223-250.

Neff KD, Kirkpatrick KL, Rude SS. (2006). Selfcompassion and adaptive psychological functioning. Educational Psychology Department, University of Texas at Austin, 1 University Station. D 5800 Austin, TX 78712, USA.

Neff KD, McGeheea P. (2010). Self-compassion and Psychological resilience among adolescents and young adults. Self and identity, 9, pp. 225240.

Reuman L, Buchholz J, Abramowitz JS. (2018). Obsessive beliefs, experiential avoidance, and cognitive fusion as predictors of obsessivecompulsive disorder symptom dimensions. Joumal of contextual behavioral science, 9, pp.15-20.

Richardson T, Freeman T, Newman-Taylor K, Bolderston H. (2018).Cognitive mechanisms in cannabis-related paranoia: Does cognitive fusion increase psychotic symptoms from THC consumption? Solent Academy of Research and Improvement Annual Conference 2018., At Algeas Bowl Hilton, West End, Southampton.

Schafer I, Harfst T, Aderhold V, Briken P, Lehmann M, Moritz S \& Naber D. (2006). Childhood trauma and dissociation in female patients with schizophrenia spectrum disorders: an exploratory study. The Joumal of nervous and mental disease, 194(2), pp. 135-138.

Seligowski AV, Miron LR., Orcutt HK. (2014). Relations Among Self-Compassion, PTSD Symptoms, and Psychological Health in a Trauma-Exposed Sample. Mindfulness, 3(7), pp. 17-22.

Simons JS, \& Gaher RM. (2005). The Distress Tolerance Scale: Development and validation of a self-report measure. Motivation and Emotion, 29(2), pp. 83-102.

Tanakaa M, Wekerle BC, Lou Schmuckc M, PagliaBoak A. (2011). The linkages among childhood maltreatment, adolescent mental health, and self-compassion in child welfare 
adolescents. Joumal of child abuse and neglect, 35,pp. 887-898.

Tedeschi RG, \& Calhoun LG. (1996). The Postraumatic Growth Inventory: Measuring the positive legacy of trauma. Joumal of traumatic stress, 9(3), pp. 455-471.

Tedeschi RG. (1999). Violence transformed: Posttraumatic growth in survivors and their societies. Aggression and Violent Behavior, 4(3), pp. 319-341.

Trindade IA, Femeira C. (2014). The impact of body image-related cognitive fusion on eating psychopathology. Eating Behavior, 15(1), pp.72-75.

Twohig MP, Hayes SC, Masuda A. (2006). Increasing willingness to experience obsessions: Acceptance and commitment therapy as a treatment for obsessive compulsive disorder. Behavior Therapy, 37(1), pp.3-13.

Van der Kooji IW, Nieuwendam J, Bipat S, Boer F, Lindauer RJ, Graafsma TL. (2015). A national study on the prevalence of child abuse and neglect in Suriname. Joumal of Child Abuse Neglect, 47, pp.153-161.

Vettese LC, Dyer CE, Li WL, \& Wekerle C. (2011). Does self-compassion mitigate the association between childhood maltreatment and later emotion regulation difficulties? A preliminary investigation. International Journal of Mental Health and Addiction, 9(5), pp. 480-491.

Vinci C, Mota N, Berenz E, \& Connolly K. (2016). Examination of the relationship between PTSD and distress tolerance in a sample of male veterans with comorbid substance use disorders. Military Psychology, 28(2), pp. 104 114.

Vujanovic AA, Litz BT, \& Farris SG. (2015). Distress tolerance as risk and maintenance factor for PTSD: Empirical and clinical implications. Comprehensive guide to postraumatic stress disorder, 1, pp. 1-13.

Vujanovic AA, Rathnayaka N, Amador CD, \& Schmitz JM. (2016). Distress tolerance: Associations with posttraumatic stress disorder symptoms among trauma-exposed, cocaine dependent adults. Behavior Modification, 40, pp. 120-143.

Zhou X, Wu X, Zhen R. (2017). Understanding the relationship between social support and posttraumatic stress disorder/posttraumatic growth among adolescents after Ya'an earthquake: The role of emotion regulation. Psychological trauma: theory, research, practice, and policy, 9(2), pp. 214.

ZvolenskyMJ, Bemstein A, Vujanovic AA. (2011). Distress Tolerance .Theory, Research, and Clinical Applications. New York, NY: Guilford Press. 